RFP-1608
April 16, 1971

RFP-1608
April 16, 1971

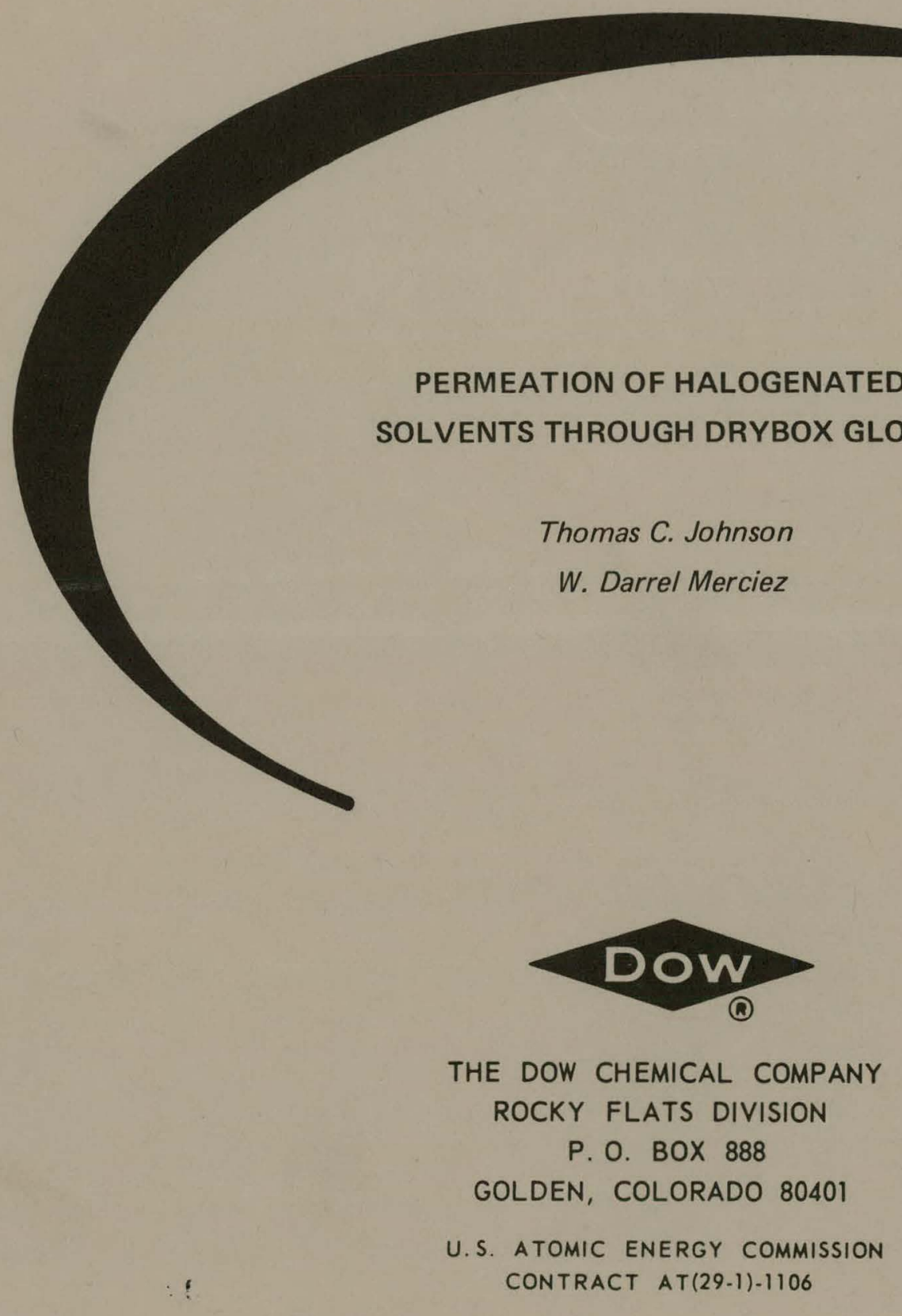

\section{1
$5|13| 7 \mid$}

$$
\text { (1) }
$$

Thomas C. Johnson

W. Darrel Merciez

\section{ES}

(n)
ISTRIBUTION OF THIS DUCUMENT IS UNLIMITE

. \\ MSTER}

$x^{2}$

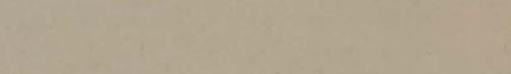

$$
\text { (a) }
$$

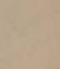




\section{DISCLAIMER}

This report was prepared as an account of work sponsored by an agency of the United States Government. Neither the United States Government nor any agency Thereof, nor any of their employees, makes any warranty, express or implied, or assumes any legal liability or responsibility for the accuracy, completeness, or usefulness of any information, apparatus, product, or process disclosed, or represents that its use would not infringe privately owned rights. Reference herein to any specific commercial product, process, or service by trade name, trademark, manufacturer, or otherwise does not necessarily constitute or imply its endorsement, recommendation, or favoring by the United States Government or any agency thereof. The views and opinions of authors expressed herein do not necessarily state or reflect those of the United States Government or any agency thereof. 


\section{DISCLAIMER}

Portions of this document may be illegible in electronic image products. Images are produced from the best available original document. 


\section{LEGAL NOTICE}

This report was prepared as an account of work sponsored by the United States Government. Neither the United States nor the United States Atomic Energy Commission, nor any of their employees, nor any of their contractors, subcontractors, or their employees, makes any warranty, expressed or implied, or assumes any legal liability or responsibility for the accuracy, completeness or usefulness of any information, apparatus, product or process disclosed, or represents that its use would not infringe privately owned rights.

Printed in the United States of America

Available from the

National Technical Information Service

U. S. Department of Commerce

Springfield, Virginia 22151

Price: Printed Copy $\$ 3.00$ : Microfiche $\$ 0.65$ 
April 16, 1971

Publication Date
RFP-1 608

UC-4 CHEMISTRY

4500 TID (56th Ed.)

\section{PERMEATION OF HALOGENATED SOLVENTS THROUGH DRYBOX GLOVES}

Thomas C. Johnson

W. Darrel Merciez .

This report was prepared as an account of work sponsored by the United States Government. Neither the United States nor the United States Atomic Energy Commission, nor any of their employees, nor any of their contractors, subcontractors, or their employees, makes any warranty, express or implied, or assumes any legal liability or responsibility for the accuracy, completeness or usefulness of any information, apparatus, product or process disclosed, or represents that its use would not infringe privately owned rights.

\section{THE DOW CHEMICAL COMPANY ROCKY FLATS DIVISION \\ P. O. BOX 888 \\ GOLDEN, COLORADO 80401}

Prepared under Controct AT(29-1)-1106

for the

Albuquerque Operations Office

U. S. Atomic Energy Commission 


\section{CONTENTS}

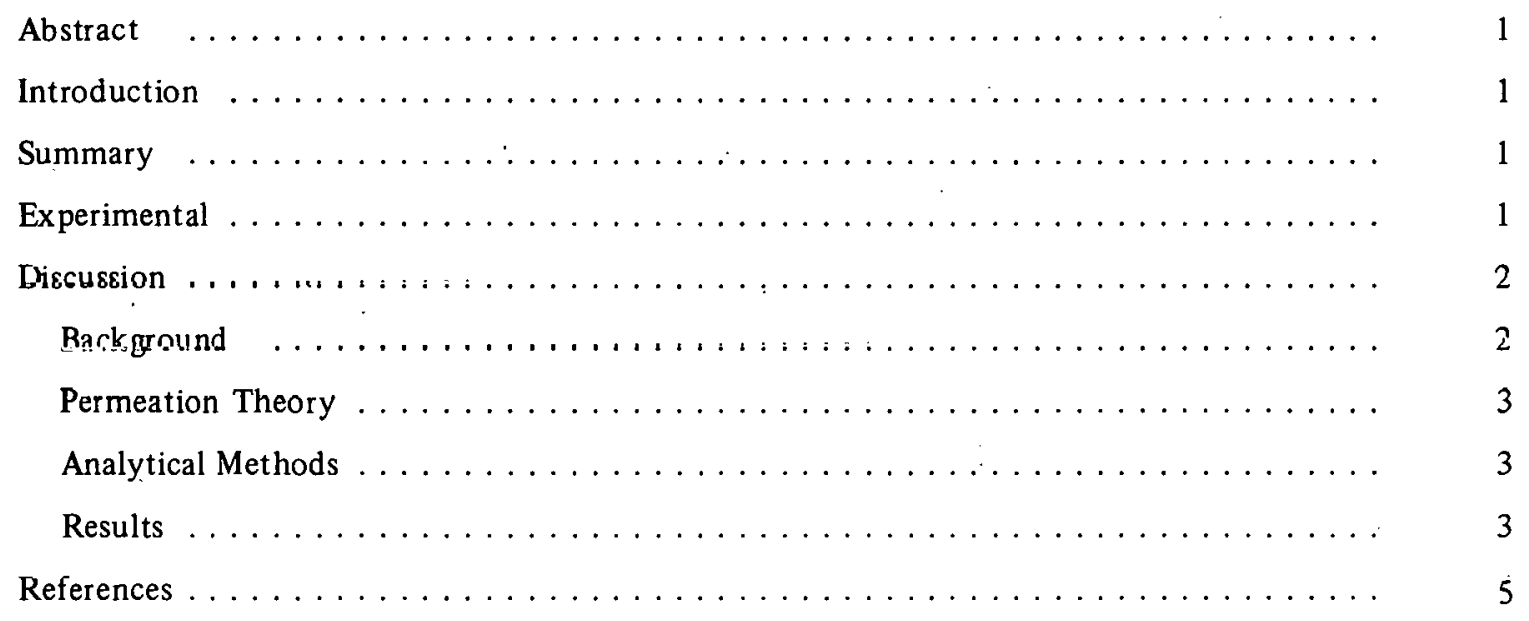




\title{
PERMEATION OF HALOGENATED SOLVENTS THROUGH DRYBOX GLOVES
}

\author{
Thomas C. Johnson \\ W. Darrel Merciez
}

\begin{abstract}
The permeation of halngenated solvents through drybox gloves was experimentally investigated. Quantitative information on the permeation rates of six common halogenated solvents through five standard types of drybox gloves was developed. Drybox gloves exposed to both solvent liquid and saturated vapor were studied. Experimental methods were adapted from standard water vapor permeation tests. Permeation of a given solvent through gloves of the same thickness was the same, within the precision of the test. There were considerable differences in permeation rates of the different solvents through similar gloves. In general, methylene chloride permeated the gloves most rapidly, follwed in order by trichloroethylene, carbon tetrachloride, methyl chloroform, perchloroethylene, and trichlorotrifluoroethane.
\end{abstract}

\section{INTRODUCTION}

Operations with plutonium metal in protective enclosures often involve the use of halogenated solvents. Operations within these enclosures are carried out primarily through drybox gloves. Drybox gloves are shoulder length elastomeric gloves mounted on circular ports in the side of the glovebox lines. The operations involving halogenated solvents often bring the drybox gloves into contact with the solvent liquid and vapor.

Halogenated solvents present varying degrees of hazards from inhalation, ingestion, and skin absorption. Since operators work with arms in drybox gloves, they could potentially contact or inhale any solvent vapor permeating the drybox glove. Quantitative information on the permeation of halogenated solvents through drybox gloves is required to assess this hazard. To develop this information, a program was undertaken to determine the permeation characteristics of halogenated solvents through drybox gloves.

\section{SUMMARY}

An investigation was made of the permeation of six halogenated solvents through five types of drybox gloves, including both leaded and unleaded gloves. Methods for this measurement are not well developed, and the methods used were adapted from standard water vapor permeation iests. The permealion rates determined by this method are valid only over a limited concentration range, but they provide a relative scale for comparing the permeation rates of the common halogenated solvents.

Permeation rates for the cases of drybox gloves exposed to both saturated solvent vapor and solvent liquid were determined. In general, methylene chloride permeated the gloves most rapidly, followed in order by trichloroethylene, carbon tetrachloride, methyl chloroform, perchloroethylene, and trichlorotrifluoroethane. This order was consistent with all of the types of drybox gloves tested. Typically, less than an order of magnitude separated the five highest permeation rates. Trichlorotrifluoroethane, however, had permeation rates more than an order of magnitude lower than the solvent nearest to it, which was perchloroethylene. This indicates that trichlorotrifluoroethane would be the safest solvent of the six tested from the aspect of operator exposure to solvent permeating the drybox glove.

The permeation rate of any given solvent through any of the four types of nominal 30-mil gloves tested was the same, within the precision of the tests. Leaded gloves had permeation rates similar to the unleaded gloves of the same thickness. Onily the 15 -mil glove showed a significantly different permeation rate. It was typically higher than the 30-mil gloves. However, comparison of the results for the 15-mil and 30-mil gloves of identical material and construction shows that permeation rate is not inversely proportional to thickness.

\section{EXPERIMENTAL}

Permeability tests were conducted according to the methods described in ASTM Designation E96-66, modified for halogenated solvents. Specifically, Procedures B and BW of ASTM E96-66 were used. Procedure $B$, as modified for these tests, consists of exposing the membrane to air saturated with solvent vapor on one side, and air with essentially zero solvent vapor content on the other side. The glove surface is not wetted with the liquid solvent. Procedure BW, as modified, consists of exposing the membrane to solvent liquid with little hydrostatic head on one side, and air with essentially zero solvent vapor content on the other side. Both test methods consist of measuring weight loss with time, of a container partially filled with solvent and having a section of the material being tested sealed across the top of the container 
The containers used in the test consist of cylindrical aluminum cups with a clamping ring around the lip for securing test samples to the cup. The containers expose $31.9 \mathrm{~cm}^{2}$ of sample area to the solvent. For the vapor permeability tests, approximately 6.5 millimeters depth of solvent ( $\sim 20$ milliliters) was put into the cup, the glove sample was sealed in place, and the cup was then maintained in an upright position in a well-ventilated area. For the wetted surface tests, solvent was placed in the cup to a depth of 5 to 10 millimeters ( $~ 16$ to 32 milliliters), the glove sample was sealed in place, and the cup was then inverted to maintain the liquid against the inside surface of the glove material. Weight loss was determined by weighing the containers at regular time intervals and subtracting these weights from the weight of the container at the start of the test. The temperature of the environment was $72^{\circ} \pm 4^{\circ} \mathrm{F}$, and barometric pressure was near $620 \mathrm{mmHg}$ during the tests. Duplicate determinations were made for each case, and the average value is reported.

The permeation rates were calculated from the plot of cumulative weight loss versus time. These relationships are usually curved with a positive slope until steady state is reached. When steady state is achieved, the weight loss-time relationship becomes linear with a positive slope. The permeation rate is numerically equal to the slope of the straight section of this curve. The slope was determined by a least squares fit of the straight section of plot.

In most cases, the solvents tested were the grades normally used for industrial degreasing. The details on the sources of the solvents used in the tests are as follows:

Chemical Name

Methylene Chloride

Tiichlorue thylene

Carbon Tetrachloride

Methyl Chloroform

Perchloroethylene

Trichlorotrifluoroethane
Tradename or Grade

Reagent Grade

Vàpor Degreasing and General Solvent Grade, PPG Industries

Reagent Grade

Solvent 111, Industrial Grade, Vulcan Chemical Company

Vapor Degreasing and General Solvent Grade, PPG Industries

Freon® TF, E. I. duPont de Nemours \& Co.
The drybox gloves tested were the standard types normally used in glovebox operations. Descriptions of the five gloves tested follow.

\section{Fifteen-mil all Neoprene glove (Charleston)*}

2. Thirty-mil all Neoprene glove (Charleston).*

3. Thirty-mil leaded Neoprene glove (Charleston).*

4. Thirty-mil leaded Neoprene glove with an outer layer of Hypalonß (Charleston).*

5. Thirty-mil all Neoprene glove (Pioneer).

\section{DISCUSSION}

\section{Background:}

Metal fabricating operations typically require the use of degreasing solvents to remove organic oils and lubricants, deposited during fabrication, from the finished metal parts. Plutonium metal fabrication is no exception and requires the use of degreasing solvents at many stages of the fabrication process. However, plutonium metal fabrication is conducted entirely in protective enclosures because of the health and radiation hazard associated with this material. Manual operations in these enclosures are performed with drybox gloves mounted on the sides of the enclosures. In many operations, the degreasing solvent comes into direct contact with the outside surface of the drybox gloves. Halogenated solvents are used almost exclusively for plutonium degreasing because of their nonflammability. Since halogenated solvents pueseıt liazards from inhalation, ingestion, and skin absorption, the quantity of solvent permeating drybox gloves is of interest in controlling the exposure of personnel to the solvents.

Several studies on the permeation of gases and vapors through drybox gloves have been reported in the literature. Most of the work has dealt with the permeation of the so.called peinlarient gases such as oxygen, nitrogen, carbon dioxide, and the three isotopes of hydrogen., ${ }^{1,3}$ Vapor permeation studies lave been limited to the study of water vapor permeation of drybox gloves. ${ }^{4,5,6}$ A study of the permeation of solvents through surgical and industrial gloves has been reported, ${ }^{7}$ but it docs not present quanlilative results that can be

\footnotetext{
* The gloves labeled Charleston were manufactured by the Charleston Rubber Company of Charleston, South Carolina. The glove designated Pioneer was manufactured by The Pioneer Rubber Company of Willard, Ohio.
} 
applied to drybox gloves. Thus, little quantitative information exists on the permeation of halogenated solvents through drybox gloves, although there are many operations where personnel work in drybox gloves exposed to halogenated solvents.

\section{Permeation Theory:}

The permeation of gases and vapors through elastomeric material can best be handled mathematically as a mass transport process. The mathematical basis for mass transport analysis is Fick's first law of diffusion. Fick's law states that diffusion flux is proportional to the concentration gradient. $^{8}$ The proportionality constant between the mass flux and the concentration gradient is the mass diffusivity. Typically, in membrane diffusion, only the permanent gases obey Fick's law of diffusion. Permeation of the easy-to-condense vapors through polymers deviates consider ably from Fick's law. Organic solvent permeation through hydrocarbon polymers is a case that deviates from Fick's law. This would include the permeation of halogenated solvent through drybox gloves. The deviation from Fick's law for the case of organic solvent permeation of hydrocarbon polymers occurs as a result of the permeant dissolving in the membrane. ${ }^{9}$ This causes a deviation because the solubility increases at a rate higher than direct proportionality with vapor pressure, and the rate of diffusion increases with the concentration of the permeant dissolved in the membranc. As a consequence, the rate of permeation increases faster than a linear rate with the vapor pressure differential, and is dependent not only on the pressure differential, hut. also on the absolute vapor pressure. As a further consequence, the permeability constant, defined as the ratio of the rate of permeation through a membrane of unit area and thick ness to the pressure differential, is not conistant. Penturability cunstants fur this type of system are valid only under the exact conditions of vapor pressure differential at which they were determined.

Another consequence of the deviation from Fick's law is the apparenitdifference between the permeabilities observed with liquids and those observed with their saturated vapors. This has best been explained by the liquid permeant conditioning the membrane to a consistency having a higher permeability. ${ }^{10}$

When conditioned membranes are used, the large differences between the liquid and vapor permeability disappear and the permeability to the saturated vapor is equal to that of the liquid. The effect of the hydrostatic head of liquid on the membrane is to effectively increase the vapor pressure of the permeant at the surface by the amount of the hydrostatic head. ${ }^{9}$. This results in an increase in the solubility of the vapor in the membrane and, consequently, an increase in the rate of permeation.

Another factor that affects the permeability constant is temperature. Variation of the permeability constant with temperature for solvent-hydrocarbon membrane combinations is complex and cannot be reliably predicted by a mathematical relation. Obtaining experimental values at each temperature of interest would be the only reliable method of determining the temperature variation of the permeability constant. In general, the permeability of vapor increases with increasing temperature.

Permeation rate is normally considered to be inversely proportional to membrane thickness. However, a study ${ }^{6}$ on the permeation of water vapor through drybox gloves demonstrated that permeation rate was inversely proportional to the thickness raised to a power. The exponents varied from 0.8 to 1.1. This type of deviation from inverse proportionality with thickness could likely exist with the permeation of organic solvents through drybox gloves.

\section{Analytical Methods:}

Methods for measurement of the permeation of easyto-condense vapors and liquids through membranes are not well developed. ASTM Designation E96-66 describes a method for measuring the permeation of water vapor through membranes at several vapor concentrations. No methods exist specifically for organic vapor permeation measurements. The method utilized in ASTM E96-66 is adaptable to organic vapor permeation tests, except that vapor concentration less than saturation cannot be as easily maintained with solvent vapors as with water vapor. The method can be used with solvent vapor at saturation only. This is the only convenient method available for testing the permeation of organic solvents through membranes.

\section{Results:}

Two types of permeability measurement were made on the drybox gloves. One method exposed the glove to saturated vapor, the other exposed the glove to the liquid solvent.

The results are reported as the weight of solvent permeating a unit area of the glove per unit time. Table I contains the results of the vapor permeation tests. Table II contains the results of liquid exposure permeation tests. The solvents in the tables are listed in the order of decreasing permeation rate. 
Table I. Permeation Rate of Halogenated Sclvent Vapor Through Typical Drybox Gloves.

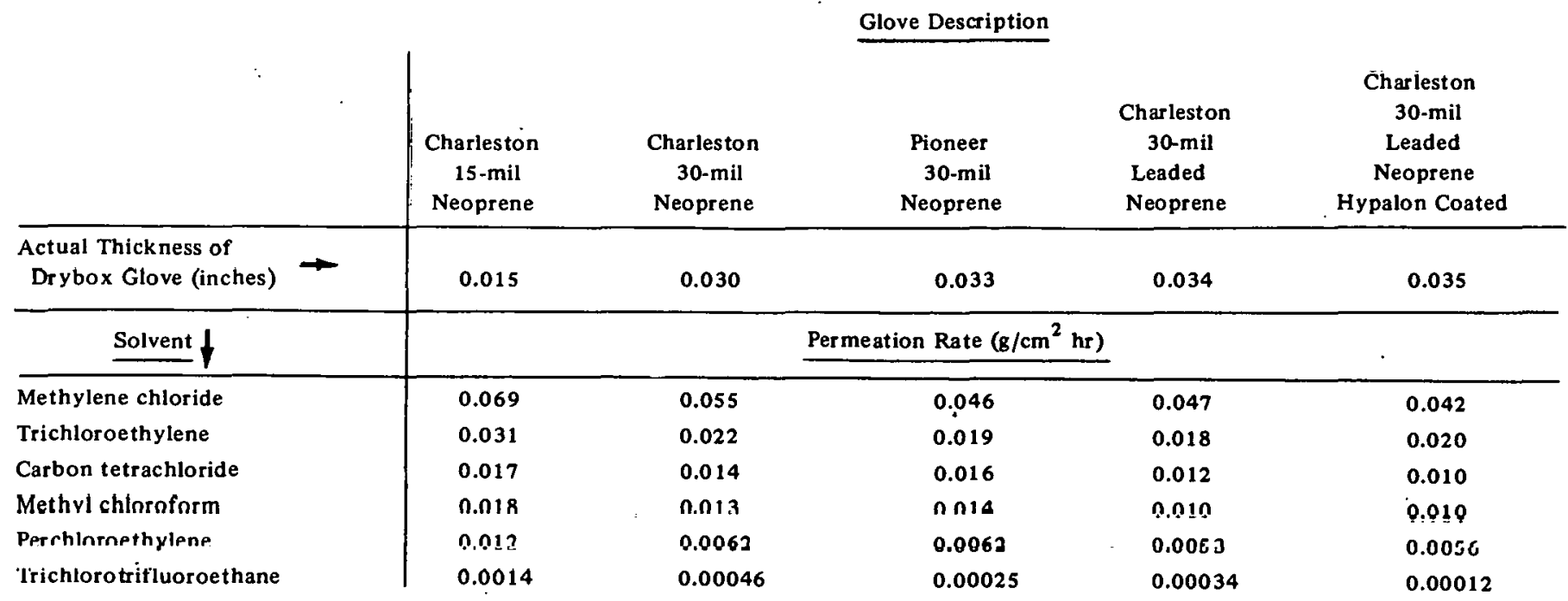

Table II. Permeation Rate of Halogenated Solvents Through Typical Drybox Gloves - Gloves Exposed to Liquid Solvent.

\begin{tabular}{|c|c|c|c|c|c|}
\hline & & & love Descri & & \\
\hline & $\begin{array}{c}\text { Charleston } \\
\text { 15-mil } \\
\text { Neoprene }\end{array}$ & $\begin{array}{c}\text { Charleston } \\
\text { 30-mil } \\
\text { Neoprene }\end{array}$ & $\begin{array}{l}\text { Pioneer } \\
\text { 30-mil } \\
\text { Neoprene }\end{array}$ & $\begin{array}{c}\text { Charleston } \\
\text { 30-mil } \\
\text { Leaded } \\
\text { Neoprene }\end{array}$ & $\begin{array}{c}\text { Charleston } \\
\text { 30-mil } \\
\text { Leaded } \\
\text { Neoprene } \\
\text { Hypalon Coated }\end{array}$ \\
\hline $\begin{array}{l}\text { Actual Thick ness of } \\
\text { Drybox Glove (inches) }\end{array}$ & 0.015 & 0.030 & 0.033 & 0.034 & 0.035 \\
\hline Solvent & & & tion Rate $(8$ & & \\
\hline Methylene chloride & 0.097 & 0.14 & 0.12 & 0.10 & 0.12 \\
\hline Trichloroethylene & 0.044 & 0.082 & 0.053 & 0.058 & 0.061 \\
\hline Carbon tetrachloride & 0.086 & 0.042 & 0.039 & 0.034 & 0.024 \\
\hline Methyl chloroform & 0.080 & 0.044 & 0.030 & 0.028 & 0.035 \\
\hline Por ohloroothylone & 0.011 & 0.020 & 0.023 & 0.020 & 0.018 \\
\hline Trichlorotrifluoroethane & 0.0011 & 0.00040 & 0.00022 & 0.00026 & 0.000099 \\
\hline
\end{tabular}

In general, the relative permeation rates of the solvents are consistent for the five types of gloves tested.

Methylene chloride permeates the gloves most rapidly, followed in order by trichloroethylene, carbon tetrachloride, methyl chloroform, perchloroethylene, and trichlorotrifluoroethane. Permeation rates for vapor exposure are more consistent than those for liquid solvent exposure. Overall, the permeation rate for liquid exposure is higher than for vapor exposure. The ratios of permeation rates for liquid exposure to vapor exposure range from approximately one to four. Within the precision of the test method, it is not possible to detect differences in the permeation rate for different typ̄es of nominal 30 -mil gloves for the same solvent. Fifteen-mil gloves are significantly more permeable than. 30-mil gloves. Application of the data in the tables should be restricted lo either relative comparisons of permeation rates or using actual numerical values for conditions near those for which the values in the tables were de termined.

The data for the vapor permeation of the 15 -mil and 30-mil Neoprene drybox gloves illustrate a deviation from the inverse relation between permeation rate and 
thickness. Comparing the permeation rate through the two Charleston Rubber Company gloves shows the permeation rate through the 30 -mil glove to be 70 to $80 \%$ of the permeation rate through the 15 -mil glove.

If a true inverse relationship exists, it would be near $50 \%$. The permeation rates for the gloves exposed to the liquid solvent exhibit no regular pattern of dependency on glove thickness, so these are not of value in assessing the effect of thickness on permeation rate.

\section{REFERENCES}

1. F. P. Evans, The Permeation of Gases Through Latex and Neoprene, (AWRE-O-56/57, UKAEA, Weapons Group, AWRE, Aldermaston Berks, England, October 23, 1957, p. 22.

2. F. P. Evans, Permeability of Some Synthetic Rubbers to Hydrogen, (AWRE-0-54/57), October 16, 1957, p. 11.

3. R. Hughes, The Permeability of Neoprene and Polyvinyl Chloride to Hydrogen, Deuterium and Tritium, (AWRE-0-17/62), February 1962, p.25.

4. J. E. Ayer, D. R. Schmitt, and R. M. Mayfield, Permeation of Water Vapor Through Polymeric
Films, Journal of Applied Polymer Science, Volume III, No. 7, 1960, pp. 1-10.

5. J. H. Rowan, Anal. Chem., 28, 3, 402, (1956) Publication Y-1075, Y-12 Plant, Union Carbide and Carbon Chemicals' Corp., Oak Ridge, Tennessee.

6. J. E. Ayer, R. M. Mayfield, and D. R. Schmitt, The Engineering Aspects of the Water Vapor Permeability of Glove Materials, Nuclear Science and Engineering, Volume 8, No. 3, September 1960.

7. D. R. McFee, How Well Do Gloves Protect Hands Against Solvents?, A.S.S.E. Journal, Volume IX, No. 5, May 1964.

8. R. B. Bird, W. E. Stewart, and E. N. Lightfoot, Transport Phenomena, John Wiley \& Sons, 1960 , p. 502.

9. A. Lebovits, Permeability of Polymers to Gases, Vapors, and Liquids, Modern Plastics, March 1966.

10. V. Staunett and H. Yasuda, Polymer Letters 1, $289,1963$. 
RFP-1 608 